Шаповал Іванна

кандидат психологічних наук, доцент кафедри практичної психології Криворізького державного педагогічного університету https://orcid.org/0000-0003-4590-8728

DOI https://doi.org/10.35619/praprv.v1i16.204

\title{
ЗРІЛІСТЬ ОСОБИСТОСТІ ЯК ІНТЕГРАЛЬНА ЗДІБНІСТЬ : ТЕОРЕТИКО-МЕТОДОЛОГІЧНЕ ОБГРУНТУВАННЯ
}

Анотація. У статті обтрунтовується розуміння феномену особистісної зрілості як інтегральної здібності, яка забезпечує особистості можливість реалізовувати вибір напрямів і способів здійснення власної активності відповідно до об'єктивних умов на основі суб'єктивних критеріїв. Наводяться висновки теоретико-логічного аналізу наукових підходів щодо сутності та психологічної природи феномену особистісної зрілості: з'ясовано концептуальну різноплановість та відсутність однозначного трактування. Представлено авторське розуміння сутності особистісної зрілості як інтегральної властивості, щзо зумовлює ї̈ здатність здійснювати вибір змісту і способів активності відповідно до об'єктивних вимог ситуащії на основі власних суб'єктивних критеріїв. Це виявлясться у здатності особистості до мотивованої саморегуляиії ефективної поведінки, збереження самоідентичності, забезпечення особистісного потенціалу, організації умов життя та реалізації особистісного зростання.

Визначено психологічний механізм формування особистісної зрілості через закріплення в індивіді системи здібностей, щзо функціонують у певній діяльності, яка забезпечує оволодіння предметами матеріальної і духовної культури, в яких втілено людські здібності. Здійснено теоретико-методологічний аналіз категорії здібності з точки зору діалектики загального, особливого та одиничного у проявах психічного. Визначено психологічну природу особистісної зрілості в широкому науково-теоретичному сенсі (на рівні загального), ї специфічні характеристики в контексті актуальних ситуацій життєдіяльності (на рівні особливого) та закономірності формування індивідуальної конфігурачії в межах психологічного простору особистості (на рівні одиничного).

Ключові слова: особистісна зрілість, особистість, здібність, свідома поведінка, індивідуальний стиль діяльності.

Постановка проблеми. У сучасній психології поняттям «зрілість» здійснюється опис людини у таких трьох аспектах. В першому аспект зрілість характеризує особливості онтогенетичного розвитку та виражає його відповідність розвитку певній віковій нормі. Тому розгляд феномену зрілості в даному аспекті полягає у визначенні механізмів та закономірностей формування вікових новоутворень особистості індивіда. Другий аспект передбачає опис зрілості як окремого етапу вікового розвитку людини (дорослості) у іiі специфічних проявах: активність, спрямованість, характерна індивідуальна структура ставлень і диспозицій особистості. Третій аспект реалізується в розкритті психологічної феноменології зрілості як особистісної характеристики, що зумовлюється різними теоретикометодологічними підходами авторів до розуміння сутності самої особистості. Тому на сьогодні у психологічній науці дана категорія «особистісна зрілість» не має однозначного трактування і досліджується як багатомірний та багаторівневий конструкт.

Аналіз останніх досліджень 3 проблеми. Спираючись на результати власного теоретико-логічного аналізу різноманітних підходів щодо розуміння психологічної природи категорії особистісної зрілості (Шаповал, 2019) та на здобутки інших дослідників, можемо констатувати багатоаспектність та різновекторність наукових пошуків: 
- якість особистості, яка прагне до зростання i розвитку, забезпечується внутрішньою єдністю ії пропріативних функцій (Олпорт, 2002);

- здатність цілісної особистості, що прагне до розвитку і самоактуалізації, до подолання перешкод і самостійного творення свого життя (Маслоу, 2010);

- цілісна інтегративна характеристика усіх життєвих сил людини, які забезпечують iii оптимальне функціонування у напрямку прогресивного розвитку (Ананьєв, 2001);

- суб'єктивні інтегровані якості особистості, які виражають систему ставлень (до себе, до інших, до світу) і дозволяють адекватно відповідати на зовнішні пливи та внутрішні процеси, тобто згідно з власними переконаннями, об'єктивними соціальними нормами й актуальними обставинами (Еріксон, 1996; Леонов \& Главатських, 2014);

- здатність особистості до організації життя відповідно до власних переконань, здатність здійснювати адекватну активність у виборі траєкторії власного життєвого шляху (Леонтьєв, 2011);

- здатність особистості до самоорганізації, що виникає на основі досягнення вікової зрілості (певний рівень розвитку ціннісно-смислової системи, відповідальності, автономіі) через прийняття та інтеграцію особистістю нових цінностей, смислів і цілей свого життя. (Солдатова \& Шляпнікова, 2015);

- ефект (результат) самостійного переживання особистістю ненормативної кризи, причому при подоланні кризової ситуації особистість, актуалізуючи свій потенціал, виходить за межі наявного досвіду, внаслідок чого набуває певних якісних змін (Штепа, 2008);

- здатність особистості встановлювати тривалі стосунки і досягати прагматичних життєвих результатів, причому в цьому аспекті особистість постає в єдності двох ролей: як суб'єкт (самостійно визначає цілі, керуючись при цьому власними уявленнями про себе) і як спостерігач (формує цілі відповідно до соціальних експектацій та зовнішньої оцінки себе іншими людьми) (Hogan\& Roberts, 2004).

Однак, зазначимо, що спільна внутрішня спрямованість цих розвідок приводить нас до висновку, що більшість науковців визначають природу особистісної зрілості в межах категорії властивостей особистості. Тому метою нашої наукової розвідки стало здійснення спроби побудови концептуального поля для операціоналізації категорії «особистісна зрілість» як інтегральної здібності та визначення її психологічних механізмів.

Виклад основного матеріалу дослідження. На наш розсуд, особистісна зрілість - це інтегральна властивість особистості, яка зумовлюе ї̈ можливість здійснювати вибір змісту і способів активності відповідно до об'єктивних вимог оточення на основі власних суб'єктивних критеріїв. Іншими словами, зріла особистість здатна здійснювати мотивовану саморегуляцію поведінки; забезпечувати ефективність і результативність цієї поведінки; зберігати внутрішню цілісність і самототожність у часі та соціально-психологічний баланс із середовищем; накопичувати, зберігати та адекватно застосовувати власний потенціал; збагачувати свій досвід та реалізовувати прогресивне особистісне зростання.

Наявність закріпленої в індивіді системи психічних властивостей, що $є$ умовою ефективності та адекватності його активності на всіх рівнях, кваліфікується як сформованість певного набору здібностей. Вважаємо, що такі здібності є компонентами особистісної зрілості. Таким чином, особистісну зрілість слід розглядати як систему, тобто певну множину елементів, що знаходяться у відношеннях і зв'язках одне 3 одним та утворюють водночас стабільну і динамічну цілісність. Тому сформована особистісна зрілість передбачає наявність відповідного комплексу здібностей, тобто закріпленої в індивіді системи психічних властивостей, які є умовою ефективності та адекватності його активності на всіх рівнях. Вони знаходяться між собою у відношенні взаємного впливу і взаємної зумовленості та інтегруються, забезпечуючи інтегральну властивість зрілості, яка не зводиться до простої суми здібностей-складових.

Здібності як властивості особистості визначають кількісно-якісні показники іiі поведінки і діяльності: успішність оволодіння новими способами та продуктивність й 
ефективність застосування таких, що вже $\epsilon$ в наявному досвіді. Тому розглянемо сутнісні особливості особистості як суб'єкта активності, зокрема їі свідомих форм.

Будь який організм (і людина у тому числі) є певною цілісністю і виділяється 3 оточення, але й разом з тим він пов'язаний з цим оточенням. Особистість як системна якість індивіда визначається включенням його у суспільні відносини і формується в процесі його спільної діяльності і спілкування. Оскільки особистість як така відносно незмінна і постійна, то, забезпечуючи людині відчуття неперервності і протяжності у часі та оточуючій обстановці, особистість представлена тими психологічними характеристиками, які відповідають за стійкі форми активності людини. Активність особистості- це здатність здійснювати суспільно значущі перетворення оточуючого середовища в процесі пристосування до нього. Такими суспільно значущими перетвореннями можуть виступати різні явища: фізичний вплив на оточуючі нематеріальні об'єкти, фізичний та духовний вплив на інших людей, власне довільне та мимовільне перетворення людини під впливом умов ії існування. Умовою реалізації активності людини є іiі здатність вступати у взаємодію 3 оточенням, тобто здатність здійснювати відповідну до умов цього оточення поведінку. Поведінка людини є формою виявлення іï активності у сукупності цілісної та послідовної системи рухових реакцій, що виникають внаслідок впливу на людину об'єктів оточуючого середовища.

Однак поведінка може бути не тільки пристосованою суб'єктом до зовнішнього світу, але й може передбачати активне пристосування оточення до цілей індивіда. Тут йдеться про свідому поведінку, через яку індивід адаптує зовнішній світ згідно з власними потребами. Реалізація свідомої поведінки відбувається за умов наявності у суб'єкта свідомості як віщого рівня психічного відображення, на основі якого процес діяльності включає попередній аналіз, порівняння і програмування можливих реакцій та вибір однієї з них як найбільш адекватної до конкретних умов.

Таким чином, свідома поведінка $є$ цілеспрямованою i довільно регульованою динамічною системою взаємодії суб'єкта зі світом відповідно до мети та умов здійснення, в процесі якої відбувається виникнення і втілення в об'єкті психічного образу та реалізація опосередкованих ним відношень суб'єкта до предметної дійсності. Зазначимо, що ефективність і продуктивність такої взаємодії має бути забезпечена певним суб'єктивним арсеналом психічних, діяльнісних, соціальних можливостей, володіння яким кваліфікується як певний рівень сформованості відповідних здібностей. Тому можемо стверджувати, що зрілість особистості виявляється у ї соиіально-психологічній самодостатності та зумовлена відповідними здібностями.

Методологічним підгрунтям нашого аналізу є діалектика загального, особливого та одиничного у проявах психічного. Аналіз здібностей на рівні загального означає необхідність визначення їхньої феноменології як властивостей, що притаманні усім людям та забезпечують їхні можливості щодо успішного оволодіння й ефективного здійснення свідомої цілеспрямованої та саморегульованої поведінки. На рівні особливого визначаються прояви цих властивостей відповідно до особливостей конкретного виду діяльності та актуальних вимог ситуації. Рівень одиничного у здібностях вказує на своєрідну конфігурацію способів дій, яка властива даному індивідові i зумовлюються його індивідуальними відмінностями, конкретними соціальними умовами та специфічними шляхами розвитку, тобто це - рівень індивідуального стилю діяльності.

На рівні загального здібності розуміються у широкому смислі, тобто як психічні властивості, що відповідають певному психічному процесу або психічній діяльності та втілюють форму зв'язку суб'єкта з об'єктивним світом (Рубінштейн, 2004). Ці властивості сформувалися у процесі суспільно-історичного розвитку людства, закріпилися і передаються від покоління до покоління в особливій зовнішній формі - у вигляді предметів людської культури як способу існування. Необхідною умовою розвитку здібностей індивіда $\epsilon$ оволодіння продуктами культури, причому на основі засвоєння принципу їх побудови. Для того, щоб людина оволоділа досягненнями людства, вона повинна, по-перше, здійснити відносно них активну й адекватну діяльність, тобто таку, яка кумульована у цих предметах i 
явищах і, тим самим, втілює людські здібності; і по-друге, вступити у відношення до цих предметів і явищ через інших людей, тобто у процесі спілкування з ними, в якому вона навчається адекватній діяльності (Леонтьєв, 1983).

Діяльність індивіда з привласнення предметів культури буде адекватною за умов виконання ним суспільно вироблених, історично складених операцій, засвоєння яких спирається не генералізацію істотних для даної галузі людської активності відношень, які, у свою чергу, закладено у кожному предметі як принцип його побудови. Опанування індивідом такими операціями, а також генералізація предметно-галузевих внутрішніх відношень, грунтуються на механізмах узагальнення психічних процесів, що функціонують у діяльності і забезпечують тї виконання (Рубінштейн, 2004). Узагальнення психічних процесів зумовлює їх перехід у психічні властивості і забезпечує перенос дій індивіда з одних умов в інші, який Мерлін (2009) виокремлює як головний критерій визначення властивостей як здібностей.

Засобом узагальнення психічних процесів $є$ спочатку їх зовнішнє, а потім внутрішнє опосередкування індивідом (зокрема на ранніх етапах онтогенезу) певної знаковосимволічної системи, що репрезентується йому в умовах спілкування з іншими людьми, яке, у свою чергу, виступає специфічною формою опосередкування психічних процесів соціальним досвідом та контекстом інтеріоризації зовнішніх соціально змодельованих форм здібностей у їхні внутрішні власне психічні форми (Виготський, 2006).

Здібності співвідносяться не з будь-яким окремим психічним процесом, а 3 їхнім комплексом. Так Шадріков (2013) цей комплекс називає функціональною системою i здібності розглядає відносно до властивостей останньої. В процесі оволодіння діяльністю формується відповідна функціональна система - сукупність пізнавальних і психомоторних процесів. Причому ця функціональна система виявляється в успішності та якісній своєрідності виконання індивідом діяльності наступним чином: пізнавальні процеси забезпечують реалізацію функції відображення, психомоторні процеси - адекватне реагування і вплив на оточення. Таким чином, автор визначає здібності як властивості пізнавальних і психомоторних процесів, що регулюють виконання певної діяльності.

Подальший теоретичний аналіз переходить на рівень особливого, оскільки передбачає розгляд здібностей як властивостей особистості в контексті конкретного виду діяльності. Цей контекст визначається специфікою операцій та основного предметно-галузевого відношення, які грунтується на цільовому та змістовно-процесуальному аспектах цієї діяльності, і тим самим зумовлюють структуру відповідної спеціальної здібності. Остання у цьому випадку розуміється у більш вузькому сенсі, тобто як комплекс психічних властивостей, що забезпечують успішність оволодіння та ефективність реалізації індивідом певного спеціального історично складеного виду діяльності.

Щодо аналізу здібностей на рівні одиничного, то тут йдеться про закономірності формування індивідуального стилю. Вважаємо за потрібне визначитись у дефініціях понять «індивідуальний стиль особистості» та «індивідуальний стиль діяльності». Перше поняття охоплює більш широке феноменологічне поле розгляду. Так Мерлін (2009), в контексті взаємозв'язку об'єктивних вимог актуальної активності та суб'єктивних властивостей особистості, зазначає, що у стилі відбиваються одночасно зовнішні умови і внутрішні можливості особистості. Відповідно індивідуальний стиль автор визначає як індивідуальносвоєрідну систему психологічних засобів, до яких цілеспрямовано або реактивно вдається людина задля якнайкращого урівноваження своєї типологічно обумовленої індивідуальності 3 наявними зовнішніми умовами.

Щодо поняття «індивідуальний стиль діяльності», то у широкому загальнонауковому сенсі воно позначає цілісну систему відмітних ознак діяльності даної людини, зумовлених особливостями іï особистості, а у вузькому прикладному сенсі - обумовлену типологічними особливостями стійку систему способів, яка складається у людини, що прагне до якнайкращого здійснення певної діяльності. До такої системи відносяться способи виконавчих та рухових актів, гностичних та орієнтувальних дій, зміни функціональних станів, якщо вони виступають як засіб досягнення мети. 
Мерлін (2009) окреслює дві основні умови, які детерминують можливість вибору індивідуального стилю діяльності: 1) наявність зони визначеності діяльності, яка обумовлена тим, що одна і та ж сама мета може бути здійснена за допомогою різних рухів, операцій, проміжних цілей; 2) прагнення суб'єкта вибирати таку індивідуальну систему рухів, операцій і проміжних цілей, завдяки якій досягається найбільша успішність діяльності. Також автор зауважує, що індивідуальний стиль діяльності особистості обумовлений потребою індивідуалізації і самоактуалізації. Оскільки певні способи дій обираються людиною для забезпечення успішності, критерієм оцінювання індивідуального стилю діяльності є іiі результативність. Відтак він може бути охарактеризований як більш менш ефективний відповідно до зовнішніх вимог щодо ефективності діяльності.

На зв'язок індивідуального стилю діяльності з її ефективністю в актуальних умовах вказує також Клімов (1982), визначаючи його як інтегральний ефект взаємодії людини 3 наявним соціальним середовищем та виокремлюючи формальні ознаки індивідуального стилю діяльності: наявність стійкої системи прийомів і способів діяльності, обумовленість цієї системи певними особистісними якостями, застосування цієї системи як засобу ефективного пристосування до об'єктивних вимог.

Також автор визначає загальну структуру індивідуального стилю. Перш за все виокремлюється ядро індивідуального стилю, в якому акумулюються такі особливості i, відповідно, способи діяльності, які мимоволі або без помітних суб'єктивних зусиль актуалізуються в даній об'єктивній обстановці на основі комплексу типологічних психофізіологічних властивостей людини: 1) особливості «А», що сприяють успіху в даній обстановці, і 2) особливості «Б», протидіючі успіху. При цьому слід зауважити на чисто функціональний характер цього ділення, оскільки одна і та ж особливість залежно від характеру об'єктивних вимог може в одному випадку виступати як категорія «А», в іншому як категорія «Б». Зазначимо, що у феноменологічному полі категорії здібності ті властивості, що складають ядро індивідуального стилю, можна трактувати як задатки, тобто індивідуальні анатомо-фізіологічні та нервово-психологічні властивості людини (Рубінштейн, 2004), властивості елементів функціональної системи (Шадріков, 2013), що обумовлюють розвиток здібностей особистості.

Особливості, що складають ядро індивідуального стилю діяльності, обумовлюючи перший пристосувальний ефект, істотно визначають напрям подальшого урівноваження особистості з середовищем, але вони не забезпечують усього необхідного пристосувального ефекту. Тому виникає інша група особливостей, які виробляються протягом деяких більш менш тривалих свідомих або стихійних пошуків. Ця група виокремлюється як своєрідна прибудова до ядра індивідуального стилю. Коли в людини $є$ певні особливості, протидіючі успішному здійсненню діяльності, то вони супроводжуються компенсаторними механізмами. Проте в міру наявності у людини типологічно обумовлених особливостей діяльності, що сприяють успішному іiі виконанню, виникають й інші елементи прибудови до ядра стилю: максимальне використання всіх можливостей, які відкриваються у зв'язку з цією категорією особливостей діяльності. Відповідно у складі прибудови до ядра індивідуального стилю визначаються дві категорії особливостей:

1) особливості «В», що мають компенсаторне значення;

2) особливості «Г», пов'язані 3 максимальним використанням позитивних пристосувальних можливостей. Таким чином, за, індивідуальний стиль діяльності особистості тим більшою мірою сформований і виражений, чим більше актуалізовано особливостей категорій «А», «В», «Г», і чим менше залишається особливостей категорії «Б», які не компенсуються (Клімов, 1982).

Отже, розгляд феномену особистісної зрілості як інтегральної здібності дозволяє визначити не тільки ії психологічну природу в широкому науково-теоретичному сенсі на рівні загального, але й виокремити іiі специфічні характеристики в контексті актуальних ситуацій життедіяльності на рівні особливого та індивідуальної конфігурації в межах психологічного простору особистості на рівні одиничного. 
Висновки і перспективи подалыших розвідок. На основі теоретико-методологічного обгрунтування психологічної природи феномену особистісної зрілості можемо визначити іiі наступним чином: це інтегральна системна здібність особистості, яка зумовлює здатність здійснювати самостійний вибір, виходячи зі стійких внутрішніх критеріїв у своїй життєдіяльності, зберігати власну цілісність та ефективність своєї діяльності на фоні постійно змінних зовнішніх умов i постійно діючих впливів, а також здійснювати цілеспрямовані впливи на оточення. Наші висновки зумовлюють напрями подальшого розгляду психологічної феноменології особистісної зрілості в аспектах функціональних проявів у цілісному особистісному просторі, операційних та змістових взаємозв'язків ії компонентів, закономірностей формування i розвитку на різних етапах онтогенезу особистості відповідно до становлення й удосконалення іiі індивідуальності.

\section{СПИСОК ПОСИЛАНЬ}

Ананьев, Б. Г. (2001). Человек как предмет познания. Санкт-Петербург: Питер.

Выготский, Л. С. (2006). Психология развития человека. Москва: Смысл.

Климов, Е. А. (1982) Индивидуальный стиль деятельности. Психология индивидуальных различий: Текстыл. Ю. Б. Гиппенрейтер \& В. Я. Романова (ред.) Москва: МГУ.

Леонов, Н. И. \& Главатских М. М. (2014) Социально-психологическая зрелость личности: интегративный подход. Известия Саратовского университета. Серия «Философия. Психология. Педагогика». 14(1), 55-66. Взято с https://www.sgu.ru/sites/default/files/journal/izvestia/pdf/2014/07/11/1-2014_55.pdf.

Леонтьев, А. Н. (1983) Об историческом подходе в изучении психики человека. Избранные психологические произведения (Т. 1, с. 96-141). Москва: Педагогика.

Леонтьев, Д. А. (2011). Новые ориентиры понимания личности: от необходимого к возможному. Вопросы психологии. 1, 3-27.

Маслоу, А. (2010). Мотивация и личность. Санкт-Петербург: Питер.

Мерлин, В. С. (2009). Психология индивидуальности. Москва: МПСИ; НПО МЭДОК.

Олпорт, Г. (2002). Становление личности. Д. А. Леонтьев (ред.), Избранные трудыл. Москва: Смысл.

Рубинштейн, С. Л. (2004). Основы общей психологии. Санкт-Петербург: Питер.

Солдатова, Е. Л. \& Шляпникова И. А. (2015). Связь Эго-идентичности и личностной зрелости. Вестник Южно-Уральского государственного университета. Серия «Психология». 8(1), 29-33. Взято 3 https://cyberleninka.ru/article/n/svyaz-egoidentichnosti-i-lichnostnoy-zrelosti/viewer.

Шадриков, В. Д. (2013). Психология деятельности и способности человека. Москва: Институт психологии РАН.

Шаповал, I. М. (2019). Особистісна зрілість як предиктор професійної ідентичності психолога. 3. М. Мірошник (ред.), Особистісна зрілість як проблема сучасної психологї̈. (Т. І, с. 24-41). Кривий Ріг: Вид. Р. А. Козлов.

Штепа, О. С. (2008). Особистісна зрілість. Модель. Опитувальник. Тренінг. Львів: Видавничий центр ЛНУ імені Івана Франка.

Эриксон, Э. (1996). Идентичность: юность и кризис. Москва: Прогресс.

Hogan, R. \& Roberts, B. W. (2004). A socioanalytic model of maturity. Journal of Career Assessment, 12, 207-217. Retrieved from https://doi.org/10.1177/1069072703255882.

\section{REFERENCES}

Ananyev, B. G. (2001). Chelovek kak predmet poznaniya [Man as a subject of knowledge]. SanktPeterburg: Piter. [in Russian].

Vygotskiy, L. S. (2006). Psikhologiya razvitiya cheloveka [Human developmental psychology]. Moskva: Smysl. [in Russian].

Klimov. E. A. (1982) Individualnyy stil deyatelnosti [Individual style of activity]. Psikhologiya individualnykh razlichiy: Teksty. Yu. B. Gippenreyter \& V. Ya. Romanova (red.). Moskva: MGU. [in Russian]. 
Leonov, N. I. \& Glavatskikh, M. M. (2014) Sotsialno-psikhologicheskaya zrelost lichnosti: integrativnyy podkhod [Socio-psychological personality maturity: an integrative approach]. Izvestiya Saratovskogo universiteta. Seriya «Filosofiya. Psikhologiya. Pedagogika». 14(1). 55-66. Vzyato s https://www.sgu.ru/sites/default/files/journal/izvestia/pdf/2014/07/11/12014 55.pdf. [in Russian].

Leontyev, A. N. (1983) Ob istoricheskom podkhode $v$ izuchenii psikhiki cheloveka [On the historical approach to the study of the human psyche]. Izbrannyye psikhologicheskiye proizvedeniya (T. 1. s. 96-141). Moskva: Pedagogika. [in Russian].

Leontyev, D. A. (2011). Novyye oriyentiry ponimaniya lichnosti: ot neobkhodimogo k vozmozhnomu [New guidelines for understanding personality: from the necessary to the possible]. Voprosy psikhologii. 1. 3-27. [in Russian].

Maslou, A. (2010). Motivatsiya i lichnost [Motivation and personality]. Sankt-Peterburg: Piter. [in Russian].

Merlin, V. S. (2009). Psikhologiya individualnosti [Psychology of individuality]. Moskva: MPSI; NPO MEDOK. [in Russian].

Olport, G. (2002). Stanovleniye lichnosti [Becoming of personality]. D. A. Leontyev (red.). Izbrannyye trudy. Moskva: Smysl. [in Russian].

Rubinshteyn, S. L. (2004). Osnovy obshchey psikhologii [Fundamentals of General Psychology]. Sankt-Peterburg: Piter. [in Russian].

Soldatova, E. L. \& Shlyapnikova, I. A. (2015). Svyaz Ego-identichnosti i lichnostnoy zrelosti. Vestnik Yuzhno-Uralskogo gosudarstvennogo universiteta [The relationship between ego identity and personal maturity]. Seriya "Psikhologiya». 8(1). 29-33. Vzyato s https://cyberleninka.ru/article/n/svyaz-ego-identichnosti-i-lichnostnoy-zrelosti/viewer. [in Russian].

Shadrikov, V. D. (2013). Psikhologiya deyatelnosti i sposobnosti cheloveka [Psychology of activity and human abilities]. Moskva: Institut psikhologii RAN. [in Russian].

Shapoval, I. M. (2019). Osobystisna zrilist yak predyktor profesiinoi identychnosti psykholoha [Personal maturity as a predictor of the professional identity of a psychologist]. Z. M. Miroshnyk (red.), Osobystisna zrilist yak problema suchasnoi psykholohii. (T. I, s. 2441). Kryvyi Rih: Vyd. R. A. Kozlov. [in Ukrainian].

Shtepa, O. S. (2008). Osobystisna zrilist. Model. Opytuvalnyk. Treninh [Personal maturity. Model. Questionnaire. Training]. Lviv: Vydavnychyi tsentr LNU imeni Ivana Franka. [in Ukrainian].

Erikson, E. (1996). Identichnost: yunost i krizis [Identity: youth and crisis]. Moskva: Progress. [in Russian].

Hogan, R. \& Roberts, B. W. (2004). A socioanalytic model of maturity. Journal of Career Assessment, 12, 207-217. Retrieved from https://doi.org/10.1177/1069072703255882. [in English]. 


\title{
PERSONAL MATURITY AS AN INTEGRAL ABILITY: THEORETICAL AND METHODOLOGICAL RATIONALE
}

\author{
Ivanna Shapoval \\ Candidate of psychological sciences, \\ Associate Professor of the Department of Practical Psychology \\ Kryvyi Rih State Pedagogical University \\ https://orcid.org/0000-0003-4590-8728
}

DOI https://doi.org/10.35619/praprv.v1i16.204

\begin{abstract}
The article substantiates the understanding of the phenomenon of personal maturity as an integral ability that provides an individual with the opportunity to implement the choice of directions and ways to carry out their own activities in accordance with objective conditions based on subjective criteria. We conducted a theoretical and logical analysis of scientific approaches to the psychological nature of the phenomenon of personal maturity, and found that scientists and researchers consider it in different ways and have not reached an unambiguous interpretation. The author's understanding of the essence of personal maturity as an integral property, which determines its ability to choose the content and methods of activity in accordance with the objective requirements of the situation on the basis of their own subjective criteria. A manifestation of this is the ability of the individual to motivated self-regulation of effective behavior, preservation of self-identity, ensuring personal potential, organization of living conditions and the realization of personal growth.

We have identified the psychological mechanism of formation of personal maturity by consolidating in the individual a system of abilities that function in a particular activity and ensures the assimilation of the individual objects of material and spiritual culture, which embodies human abilities. Theoretical and methodological analysis of the category of ability in terms of the dialectic of general, special and individual in the manifestations of mental. The psychological nature of personal maturity in a broad scientific and theoretical sense (at the general level), its specific characteristics in the context of current life situations (at the special level) and patterns of formation of individual configuration within the psychological space of personality (at the individual level).
\end{abstract}

Key words: personal maturity, personality, ability, conscious behavior, individual style of activity. 